\title{
HUBUNGAN ANTARA INISIASI MENYUSUI DINI DENGAN KECEPATAN WAKTU PENGELUARAN PLASENTA PADA KALA III PERSALINAN DI RUANG DAHLIA I RSU USD GAMBIRAN KOTA KEDIRI,
}

\author{
Yunarsih, Dwi Rahayu \\ Akademi Keperawatan Dharma Husada Kediri
}

\begin{abstract}
Breaseeding (Early initiation) or the beginning of early breastfeeding is a natural process of restoring a human baby to suckle, by allowing the baby to find and suck the milk itself, within the first hour of the beginning of life. touch the baby's hands at the nipple and surrounding, sucking and licking a baby on the nipple stimulates the hormone oxytocin can help the uterus contract, helping expulsion of the placenta and reduce maternal bleeding. Normally, the placenta will be separated in less than 30 minutes after birth. The purpose of this study is the Knowing the relationship between early initiation of breastfeeding plasenta.Rancang spending time with the speed of this study was a cohort (longitudinal prospective). In this study, the speed of early initiation of breastfeeding in question are researchers doing early initiation of breastfeeding in a way after the baby is born and then dried body and the baby's head and placed the baby the mother's chest between the two breasts and then the mother and baby covered together. While time expulsion of the placenta (the third stage) is the time between the issuance of the fetus and placenta using random sampling and diambilsampelsebanyak tehniksampling 15 orangsesuaikriteriayang determined. To analyze the relationship between the relationship between early initiation of breastfeeding with spending time digunakanujistatistik $\mathrm{T}$ testdengan help SPSS20ForWindows.Berdasarkandari ujihasilanalisakorelasi $\mathrm{T}$ test using SPSS20 For Window obtained hasilp $(0,037)<(0.05), \alpha$ which means that $\mathrm{H} 0$ and $\mathrm{H} 1$ accepted meaning adahubunganyangsignifikanantarahubungan between breaseeding with placenta spending time at Dahlia Lounge I RSU USD Gambiran Kediri. This is because of the stimulation of the nipples when IMD stimulates oxytocin expenditures that increase the force of contraction uetus. In further research should consider other factors that increase the strength of uterine contractions.
\end{abstract}

\section{KeyWord: early breastfeeding initiation, speed removal of placenta}

\section{PENDAHULUAN}

Inisiasi menyusui dini (Early initiation) atau permulaan menyusu dini adalah proses alami mengembalikan bayi manusia untuk menyusu, yaitu dengan memberi kesempatan pada bayi untuk mencari dan menghisap ASI sendiri, dalam satu jam pertama pada awal kehidupannya

Manfaat inisiasi menyusui dini untuk bayi antara lain menghangatkan bayi dengan cepat yaitu selama bayi merangkak mencari payudara dan ini akan menurunkan kematian karena kedinginan (hipothermi) sedangkan manfaat bagi ibu adalah hentakan kepala bayi ke dada ibu, sentuhan tangan bayi di puting susu dan sekitarnya, hisapan dan jilatan bayi pada puting susu merangsang hormon oksitosin yang dapat membantu rahim berkontraksi sehingga membantu pengeluaran plasenta dan mengurangi perdarahan ibu. Normalnya plasenta akan lepas dalam waktu kurang dari 30 menit setelah kelahiran bayi.

Mengetahui hubungan antara inisiasi menyusui dini dengan kecepatan waktu pengeluaran plasenta. 


\section{METODE PENELITIAN}

Rancang bangun penelitian ini adalah kohor (longitudinal prospektif). Dalam penelitian ini, kecepatan inisiasi menyusui dini yang dimaksud adalah peneliti melakukan inisiasi menyusui dini dengan cara setelah bayi lahir kemudian dikeringkan badan dan kepala bayi lalu bayi diletakkan didada ibu diantara duapayudara kemudian ibu dan bayi diselimuti bersama. Sedangkan waktu pengeluaran plasenta (kala III) adalah waktu antara pengeluaran janin dan pengeluaran plasenta dengan menggunakan tehnik sampling random sampling dan diambil sampel sebanyak 15 orang sesuai kriteria yang ditentukan. Penelitian ini dilakukan pada bulan Agustus sampe Oktober 2016.Untuk menganalisa hubungan antara hubungan antara inisiasi menyusui dini dengan waktu pengeluaran digunakan uji statistik $\mathrm{T}$ testdengan bantuan SPSS 20 For Windows.

\section{HASIL PENELITIAN}

Berdasarkan dari uji hasil analisa korelasi T test dengan menggunakan SPSS 20 For Window diperoleh hasil $\mathrm{p}(0,037)$ $<\alpha(0,05)$, yang artinya $\mathrm{H} 0$ ditolak dan $\mathrm{H} 1$ diterima berarti ada hubungan yang signifikan antara hubungan antara inisiasi menyusui dini dengan waktu pengeluaran plasenta di Ruang Dahlia I RSU USD Gambiran Kota Kediri.

\section{PEMBAHASAN}

Hasil penelitian ini menunjukkan bahwa ada hubungan yang signifikan antara inisiasi menyusui dini dengan kecepatan waktu pengeluaran plasenta. Oleh karena segera setelah bayi lahir keringkan dan laukan IMD. Perdarahan masih menduduki urutan pertama penyebab kematian ibu di Indonesia. Salah satu tindakan yang tepat adalah dengan melakukan inisiasi menyusui dini. Pada saat dilakukan inisiasi menyusui dini sentuhan, jilatan, usapan pada puting susu ibu akan merangsang pengeluaran hormon oxyitosin yang dapat merangsang kontraksi uterus sehingga menurunkan resiko perdarahan pada kala III.

Ada penelitian yang hampir serupa dengan penelitian ini yaitu penelitian yang diadakan di Australia oleh Thompson et al. yang menunjukkan hasil bahwa ada hubungan antara kejadian perdarahan pada kala III dengan penundaan inisiasi menyusui dini. Perbedaan penelitian ini dengan penelitian yang peneliti lakukan adalah pada penelitian ini respondennya ibu yang mengalami perdarahan setelah melahirkan kemudian dihubungkan dengan apakah ibu melakukan inisiasi menyusui dini, sehingga kesimpulan penelitiannya bahwa ibu yang mengalami perdarahan setelah melahirkan ada hubungan dengan penundaan inisiasi menyusui dini. Sedangkan penelitian yang peneliti lakukan, respondennya adalah ibu yang melahirkan normal kemudian dilakukan inisiasi menyusui dini diobservasi waktunya kecepatan waktu pengeluaran plasenta dan ternyata setelah dilakukan inisiasi menyusui dini terdapat peningatan kecepatan pengeluaran plasenta sehingga menurunkan resiko perdarahan pada Kala III, perdarahan yang keluar masih dalam batas normal yaitu kurang dari $500 \mathrm{cc}$.

Penelitian serupa juga dilakukan oleh Rahmaningtyas dkk. di Kediri dengan hasil penelitian ada perbedaan kontraksi uterus pada ibu post partum sebelum dan sesudah melaksanakan inisiasi menyusui dini.

Perbedaan dengan penelitian yang peneliti lakukan adalah peneliti tersebut menghubungkan antara inisiasi menyusui dini dengan variabel kontraksi uterus yang nantinya juga akan berpengaruh terhadap volume perdarahan ibu, sedangkan penelitian yang peneliti lakukan saat ini dihubungkan dengan variabel kecepatan pengelauarn plasenta..

Pada ibu setelah melaksanakan inisiasi menyusui dini, kontraksi uterusnya lebih baik dibandingkan dengan sebelum dilaksanakan inisiasi menyusui dini. Hal ini sesuai dengan yang diuraikan (Aprilia, 2009) bahwa pada saat dilakukan inisiasi menyusui dini sentuhan, jilatan, usapan pada puting susu ibu akan 
merangsang pengeluaran hormon oxyitosin yang dapat merangsang kontraksi uterus sehingga meningkatkan kecepatan pengeluaran plasenta.

Menurut (Mander, 1998) kontraksi uterus yang baik akan membantu mempercepat pelepasan plasenta dari dinding rahim dan secara fisiologis akan menyebabkan kontraksi serabut-serabut miometrium yang mengelilingi pembuluh darah yang memvaskularisasi daerah implantasi plasenta sehingga pembuluhpembuluh darah tersebut terjepit dan akan menutup dengan demikian perdarahan akan berkurang. Sehingga semakin cepat inisiasi menyusui dini maka semakin sedikit perdarahan yang keluar pada kala empat.

\section{KESIMPULAN}

Terdapat hubungan yang signifikan antara hubungan antara inisiasi menyusui dini dengan kecepatan waktu pengeluaran plasenta di Ruang Dahlia I RSU USD Gambiran Kota Kediri karena dengan IMD dapat merangsang pengeluaran hormon oxyitosin yang dapat merangsang kontraksi uterus sehingga meningkatkan kecepatan waktupengeluaran plasenta.

\section{SARAN}

Hendaknya pengambil kebijakan pada tatanan pelayanan kesehatan dapat lebih meningkatkan pendidikan kesehatan pada ibu-ibu hamil tentang pentingnya pelaksanaan inisiasi menyusui dini yang tepat sehingga angka kejadian perdarahan post partum sebagai penyebab utama kematian ibu dapat ditekan.

Dalam penelitian ini faktor-faktor lain yang mempengaruhi kontraksi uterus tidak diteliti dan dianalisis secara mendalam, sehingga untuk peneliti selanjutnya hendaknya memperhatikan faktor-faktor lain yang mempengaruhi kontraksi uterus.

\section{DAFTAR PUSTAKA}

Admin. (2010). Inisiasi Menyusui Dini.http://kti-inisiasi-menyusui dini.blogspot.com/2011/10/perdara han-setelah-bayi-lahir.html.

diakses tanggal 20 Juli 2016.

Ana. (2010). Perdarahan Penyebab Utama Kematian Ibu. http://health. kompas.com $/ \mathrm{read} / 2010 / 06 / 24 / 084$ 82448/Perdrhan.Penyebab.Utama.

Kematian.Ibu. diakses tanggal 13 Juli 2016.

Aprilia. (2009). Analisis Sosialisasi Program Inisiasi Menyusui Dini Dan Asi Eksklusif Kepada Bidan Di Kabupaten Klaten. Tesis. Universitas Diponegoro. Semarang.

Frisda. (2010). Faktor-faktor Pada bidan Yang Mempengaruhi Praktik Inisiasi Menyusui Dini. Tesis.Universitas Diponegoro Semarang.

Gusnita. (2008). Inisiasi Menyusui Dini Cegah Perdarahan Ibu Melahirkan.

http://news.detik.com/read/2008/0 8/03/101215/981982/10/inisiasime nyusu-dini-cegah-pendarahan-ibumelahirkan. diakses tanggal 10 Agustus 2016.

Haryanti. (2011 ). Faktor-faktor Yang Mempengaruhi Pelaksanaan Inisiasi Menyusui Dini. Skripsi. Stikes Muhammadiyah GombongJawa Tengah.

Hernawati. (2011). Analisis Kematian Ibu Di Indonesia 2010. Jakarta: Riskesdas dan Laporan Rutin KIA.

Idris. (2009). Peran Faktor Perilaku Dalam Penerapan Inisiasi Menyusui Dini di Kota Pare Pare. Tesis. Universitas Hasanuddin Makasar.

Kuntoro. (2008). Metode Sampling dan Penentuan Besar sampel. Surabaya: Penerbit Pustaka Melati. Nakao, Moji, Honda, Oishi, (2008).Initiation of breastfeeding within 120 minutes after birth is associated with breastfeeding at four months among Japanese women: A self-administered questionnaire survey. International Breastfeeding Journal 2008, 3:1 doi:10.1186/1746-4358-3-1 
Potter, Patricia A \& Perry, Anne G. (1997). Fundamental of Nursing. Concepts, Process, and Practice. Missouri: Mosby Year Book

Purnamasari Yeni .(2011). Inisiasi menyusui

Dini.http://www.lkc.or.id/ yenipurnamasari /2011/09/22/apaitu-imd/. diakses tanggal 10Agustus 2016

Rahmaningtyas. Wijanti, Hardjito .(2010). Perbedaan kekuatan kontraksi uterus pada ibu post partum antara sebelum dan sesudah melaksanakan inisiasi menyusui dini. jurnal penelitian kesehatan forikes vol.1 No.3.ISSN 20863098

Ranggaahdiat. (2011). IMD (Inisiasi Menyusui Dini). http://devyranggaahdiat. wordpress.com/2011/01/13/imdinisiasi-menyusi-dini/diakses tanggal 16 September 2016.

Reeder., Martin Koniak-Griffin. (2010). Keperawatan Maternitas, Kesehatan wanita,Bayi dan Keluarga.Edisi 18,Volume 1. Jakarta: Penerbit Buku Kedokteran EGC

Roesli, Utami (2008). Inisiasi Menyusui Dini. Jakarta: Penerbit Buku Kedokteran EGC

Theresia Catur Wulan Setyaningrum. (2009). Pengaruh inisiasi menyusui dini terhadap jumlah perdarahan pada kala II sampai kala IV di Rumah Sakit Umum Daerah Kota Surakarta.Skripsi. Universitas Sebelas Maret Solo.

Thompson.,

Heal.,

Robert.,Ellwood.(2010). Women's breastfeeding experiences following a significant primary postpartum haemorrhage: A multicentre cohort studi International Breastfeeding.Journal, 5:5 doi:10.1186/1746-4358-5-5

Weisbrod., Sheppard., Chernofsky., Gage., (2009). Emergent management of postpartum hemorrhage for the general and acute care surgeon. World Journal of Emergency Surgery 2009, 4:43 doi:10.1186/1749-7922-4-43

Zuliani.(2011). Program Pelaksanaan IMD di Indonesia. http:// elvizulianisehatidotcom.wordpress .com/category/kesehatan-populer/ diakses tanggal 16 September 2016 